\title{
The Effect of Pertussis Vaccine on the Insulin- Dependent Diabetes Induced by Streptozotocin in Mice
}

\author{
SHIH-WEN HUANG, ${ }^{(28)}$ GLEN TAYLOR, AND AHMED BASID \\ Department of Pediatrics, University of Maryland School of Medicine, Baltimore, Maryland USA
}

\begin{abstract}
Summary
Protective effect of pertussis vaccine (PV) against the development of insulin-dependent diabetes (IDD) induced by streptozotocin (STZ) in young CD-1 male mice were studied. When PV at a dose of $1.2 \times 10^{10}$ microorganism was administered on -10 , 0 , or $+4 \mathrm{~d}$ relative to a single injection of $\mathrm{STZ}(60 \mathrm{mg} / \mathrm{kg}$ body wt) on $\mathrm{d} 0$, it completely aborted the development of IDD after $140 \mathrm{~d}$. When PV was given on $+30 \mathrm{~d}$ after STZ injection and followed by PV booster injections, $66 \%$ of mice reverted to normoglycemic state. Intact islet cells in the pancreas were confirmed by histologic findings and normal plasma insulin values. The effect of PV was compared with that of boiled PV in another model of IDD induced by multiple injections of STZ (40 $\mathrm{mg} / \mathrm{kg}$ for five doses). In this model, $60 \%$ of mice either remained or reverted to normoglycemic state with PV and booster injections whereas boiled PV protected $40 \%$ of mice from developing IDD. The protective effect appeared to reside in the biologic property of both pertussigen and endotoxin of Bordetella pertussis.
\end{abstract}

\section{Abbreviations}

bPV, boiled pertussis vaccine

HSF, histamine sensitizing factor

IAP, islet cell activating protein

IDD, insulin-dependent diabetes

LPF, lymphocyte promoting factor

$P V$, pertussis vaccine

STZ, streptozotocin

STZ, given either as a single dose $(8,16)$ or in multiple doses $(13,14,22)$, may produce a permanent form of IDD in young mice. These models have been useful in studying the pathogenesis of IDD also known as juvenile onset diabetes because it resembles many biochemical, immunologic, and histologic changes reported in recent onset IDD in man $(8,13,22)$. It also provides the opportunity for the study of intervention at early stages of the disease which invariably carries high frequency of complication in patients in spite of insulin treatment. Using a single dose STZ model, we previously showed that a prior injection of whole PV before STZ injection would protect susceptible, young CD-1 mice from developing IDD (9). The protection was confirmed by findings of normal blood glucose level, normal insulin level, normal glucose tolerance test, and the histology of islets in pancreas. In this study, we chose the single dose STZ model and injected PV at various time intervals after STZ injection in order to determine the time course of this protection from IDD. In another experiment, we chose also the multiple dose STZ model to compare the effect of PV versus bPV and to evaluate the role of endotoxin in the protection. Whenever it was indicated, successive booster injection of PV or bPV was employed to assess its effect on established hyperglycemia. This report describes the results of serial blood glucose changes in these groups and histologic findings in islet cells in pancreas in each animal and compare the results with the overall incidence of IDD in each group at the end of the experiment.

\section{MATERIALS AND METHODS}

Animals. Young CD-1 male mice (aged 35 d) (Charles River Laboratory, Wilmington, MA) were given laboratory chow and water ad libitum for $10 \mathrm{~d}$ before experimentation. Their weights were determined weekly throughout the experiments.

STZ. STZ (a gift from Dr. Paul W. O'Connell of Upjohn Co., Kalamazoo, MI; Lot No. 60, 273-2) was dissolved in citrate buffer, $\mathrm{pH} 4.2$, immediately before the experiment.

$P V$. PV (a gift from Dr. Charles R. Manclark of Bureau of Biologics, FDA, Rockville, MD; Lot 76) in the form of wholecell Bordetella pertussis vaccine was given at a dose of $0.25 \mathrm{ml}$ containing approximately $1.2 \times 10^{10}$ organisms by intraperitoneal injection. The control animal received $0.25 \mathrm{ml}$ of $0.01 \%$ merthiolate solution which was used as a diluent for the vaccine. bPV was prepared by incubating the reconstituted PV at $80^{\circ} \mathrm{C}$ for $1 / 2 \mathrm{~h}$. This would destroy most of the heat labile biologic factor but would preserve the endotoxin (19).

Blood glucose and insulin. The whole blood glucose was measured as previously described (17) and the radioimmunoassay of insulin has also been described (9).

Examination of the pancreas. The mice were exsanguinated under ether anesthesia. The pancreas were removed and immediately fixed for paraffin sectioning in the mixture of $4 \%$ formaldehyde and $1 \%$ glutaraldehyde in a buffer of $176 \mathrm{mosmol} / \mathrm{L}$ (18). After H\&E stain, at least 45 islets from different portion of each pancreas were examined for histologic changes compatible with the insulitis or the development of IDD (9).

Experiment I. Animals were divided into five groups ( $n=6$ each). To each animal STZ was administered at a dose of $60 \mathrm{mg} /$ $\mathrm{kg}$ on $\mathrm{d} 0$. PV was injected on $\mathrm{d}-10,0,+4$, and +30 relative to STZ injection in four separate groups of mice. The control group received STZ and $0.01 \%$ merthiolate solution. Serial blood glucose was measured and plasma insulin was assayed at the termination of the experiment. Repeated injections of PV were given to mice that developed hyperglycemia (blood glucose above $200 \mathrm{mg} \%$ ). The pancreas of each mouse was examined at the end of the experiment.

Experiment II. In this experiment, STZ was administered daily on 5 successive $\mathrm{d}$ at a dose of $40 \mathrm{mg} / \mathrm{kg}$. PV or bPV was injected $3 \mathrm{~d}$ before STZ injection in two groups ( $n=10$ each). Another group $(n=10)$ received $0.01 \%$ merthiolate solution before STZ 
injection. Control group $(n=6)$ only received $0.01 \%$ merthiolate solution. Blood glucose was measured serially and booster injection of either PV or bPV was given in respective groups whenever hyperglycemia developed in mice. At the termination of the experiment, histology of pancreas was examined in each mouse.

Statistical Analysis. We employed a $t$ test for small samples and chi-square test for the analysis of the data.

\section{RESULTS}

Figure 1 illustrates the time course of blood glucose levels of mice injected with a single dose of STZ $(60 \mathrm{mg} / \mathrm{kg})$ and with PV which was given at different schedules. The group that received only STZ developed hyperglycemia 4-6 wk after the injection. The outcome of the other group of mice receiving PV either before $(-10 \mathrm{~d})$, simultaneously $(0 \mathrm{~d})$, or after $(+4 \mathrm{~d})$ STZ injection appeared to be the same. All mice that received PV, experienced a hypoglycemic state followed by normoglycemia that lasted for at least $20 \mathrm{wk}$. In no instance did any of those mice develop hyperglycemia. In the group of mice that received PV when they were already hyperglycemic on d 30 after STZ injection, normoglycemia returned and lasted for nearly $8-10 \mathrm{wk}$ before hyperglycemia reappeared in the 12 th wk. After a booster dose at that time of PV, four of six mice (66\%) in the hyperglycemic group returned to a normoglycemic state which lasted more than 6 wk whereas the remaining two mice had developed irreversible hyperglycemia (Fig. 1). It thus appeared a timely injection of PV might abort STZ-induced IDD in those experimental conditions.

The plasma insulin values are presented in Table 1 . The control mice which received STZ uniformly developed hypoinsulinemia $(15.7 \mu \mathrm{U} / \mathrm{ml})$ by $30 \mathrm{~d}$ after single injection of STZ. Those mice protected by PV all retained normal insulin values.
Table 1. Determinations of plasma insulin values in mice of experiment $I^{*}$

\begin{tabular}{ccc}
\hline $\begin{array}{c}\text { Injection of PV } \\
\text { relative to STZ } \\
\text { (in d) }\end{array}$ & $\begin{array}{c}\text { Days after } \\
\text { STZ injection }\end{array}$ & $\begin{array}{c}\text { Insulin }(\mu \mathrm{U} / \mathrm{ml}) \\
(\text { mean } \pm \mathrm{SEM})\end{array}$ \\
\hline-10 & 140 & $53.4 \pm 1.0$ \\
0 & 140 & $55.2 \pm 1.1$ \\
+4 & 140 & $50.0 \pm 1.6$ \\
+30 & 30 & $17.9 \pm 4.0$ \\
+30 & 36 & $81.0 \pm 2.3$ \\
+30 & 140 & $54.6 \pm 3.0$ \\
STZ only (no PV) & 30 & $15.7 \pm 3.6$ \\
STZ only (no PV) & 140 & $6.5 \pm 1.1$ \\
Control (no PV or STZ) & 140 & $59.2 \pm 1.7$ \\
\hline
\end{tabular}

${ }^{*} n=6$ in each group. Each mouse received streptozotoan (STZ) $(60$ $\mathrm{mg} / \mathrm{kg}$ ) on $\mathrm{d} 0$. PV, pertussis vaccine. Significant difference was present $(\mathrm{P}<0.01)$ when compared with animals receiving no intervention.

The mice which received STZ developed hypoinsulinemia on $\mathrm{d}$ 30 but the injection of PV reversed the plasma insulin values toward normal until the end of the experiment. As previously described, those mice that received STZ uniformly showed a significant decrease in size as well as changes of morphology of islets in pancreas $(8,9)$ (Fig. 2) as compared with controls (Fig. 3 ). Less than $10 \%$ of islets in those diabetic mice still showed traces of inflammatory cell infiltrates (Fig. 4). Those histologic changes were consistently compatible with a significant decrease in their plasma insulin values.

Figure 5 shows serial blood glucose changes in mice that received PV or bPV before multiple injection of STZ $(40 \mathrm{mg} / \mathrm{kg}$

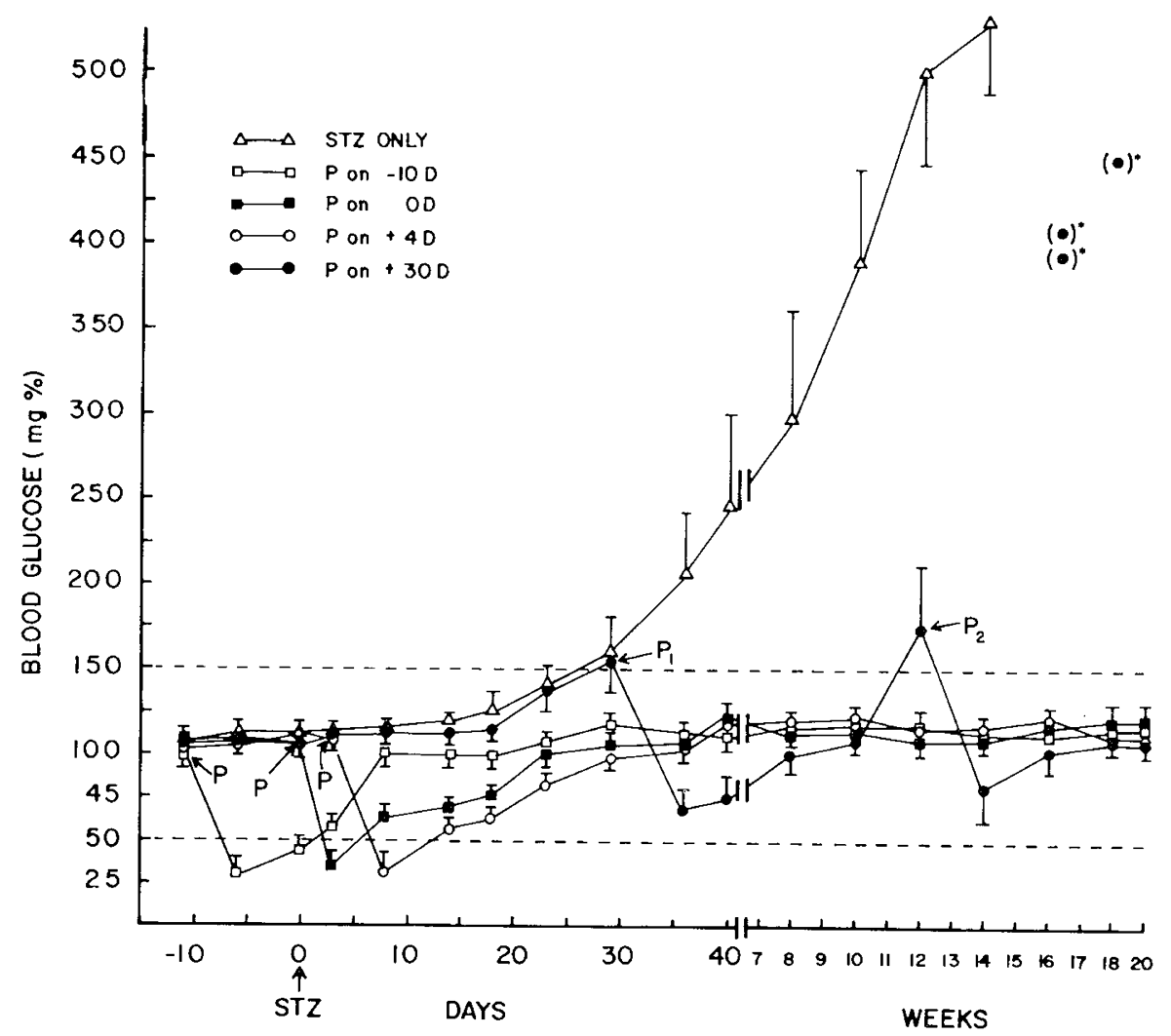

Fig. 1. The sequential changes of blood glucose levels in five groups of mice ( $n=6$ each) receiving injection of pertussis vaccine (PV) and/or streptozotocin (STZ) respectively with varying schedule in Experiment I. PV was administered IP in $0.25 \mathrm{ml}$ containing $1.2 \times 10^{10}$ organisms. STZ was injected IP at single dose of $60 \mathrm{mg} / \mathrm{kg}$ body wt per mousc. The vertical hars indicate I SD from the mean values. The normal range of blood glucose levels is expressed by two hroken lines. $P_{1}$ indicates the first injection of PV given on the 30th d after STZ (- - $-P_{2}$ is the booster injection given after $12 \mathrm{wk}$. Asterisk indicates separate blood glucose values from two mice of the same group (significant hyperglycemia inspite of the booster PV injection. 


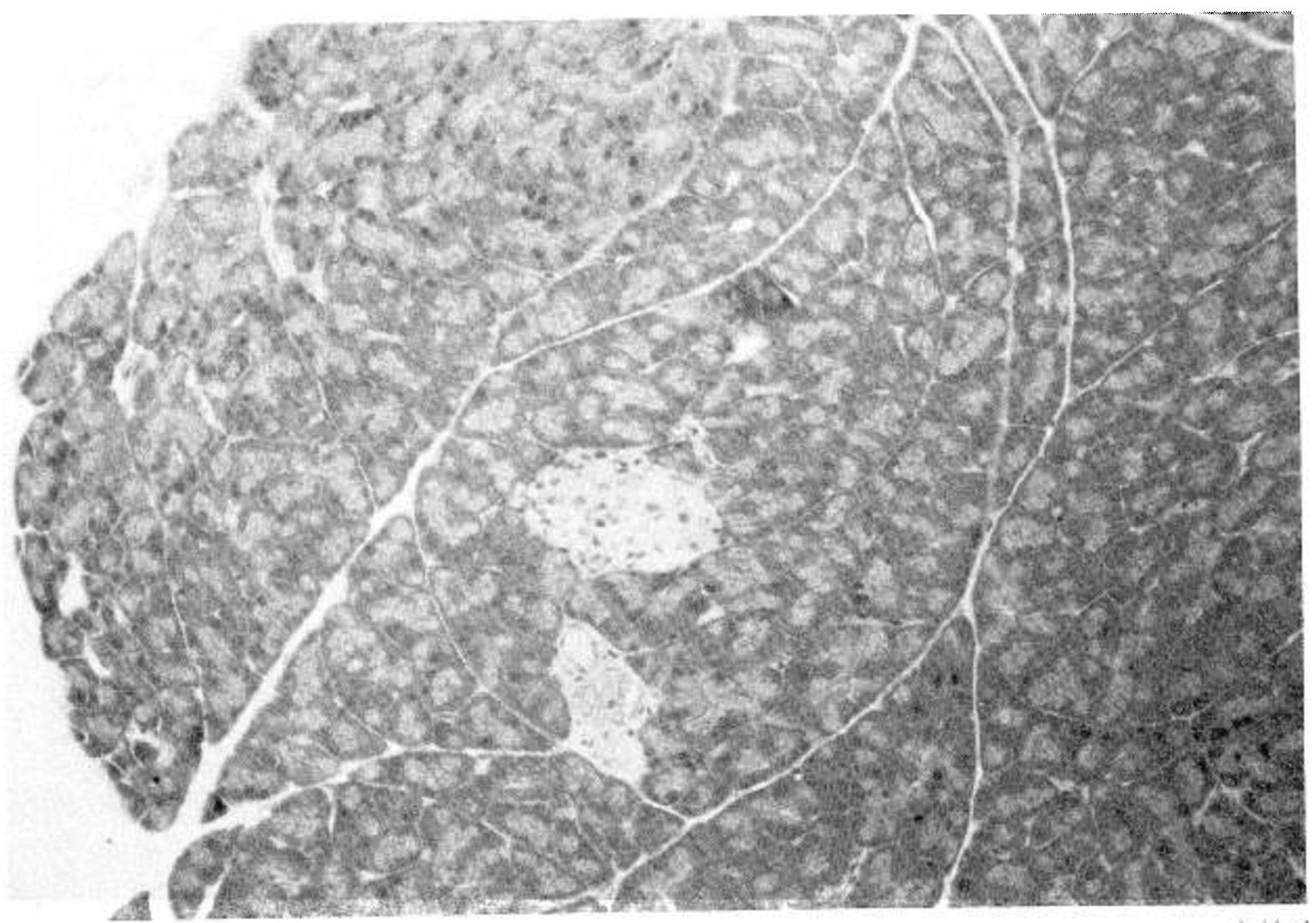

Fig. 2. The pancreatic tissue was obtained on d 60 after a single injection of streptozotocin in Experiment 1 (islets show a remarkable decrease in size and its appearance).

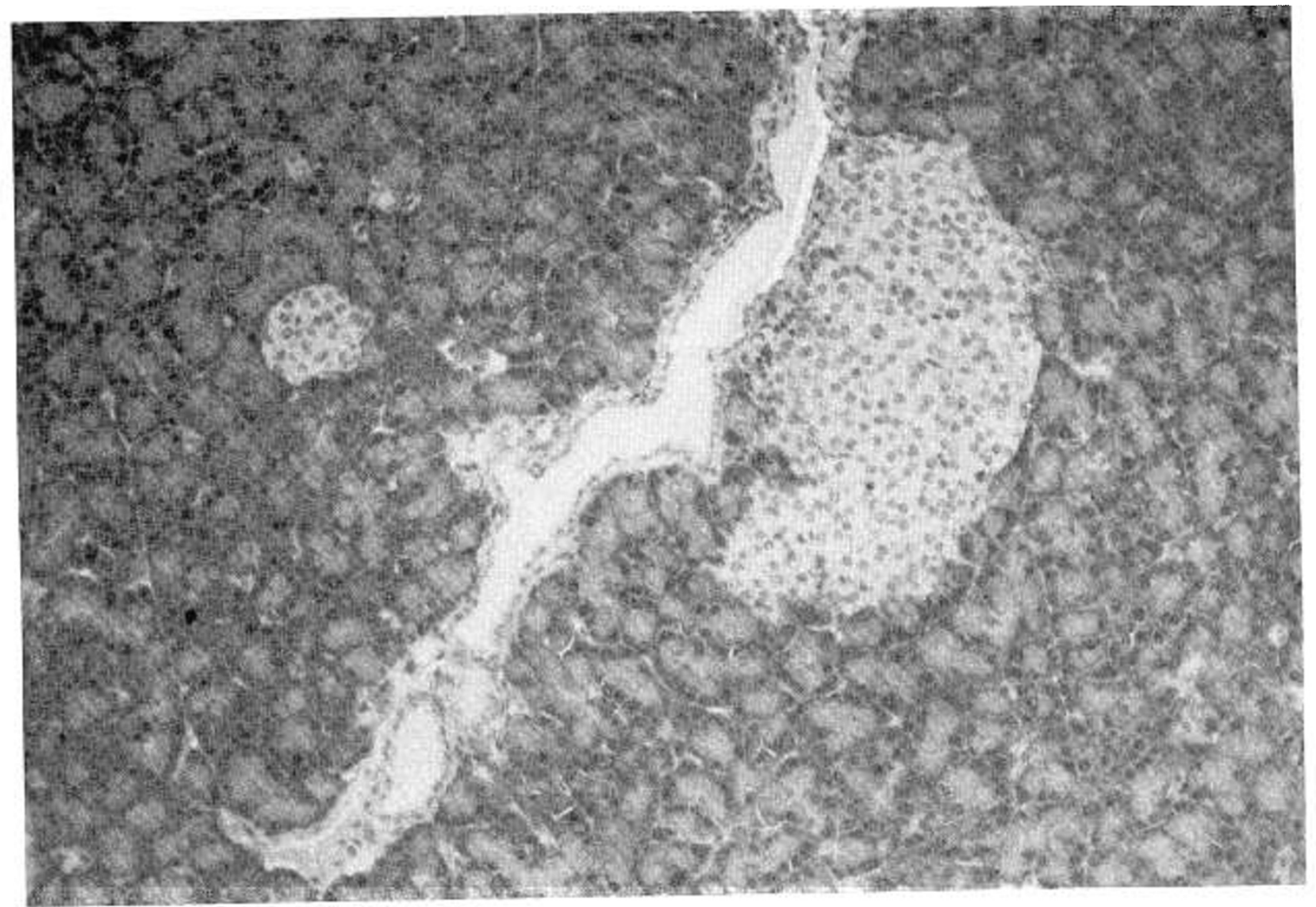

Fig. 3. The pancreatic tissue was obtained on $\mathrm{d} 60$ from one of the control mice not receiving streptozotocin injection in Experiment $\mathrm{I}$. The islet cells were much more populated as compared with Figure 2. 


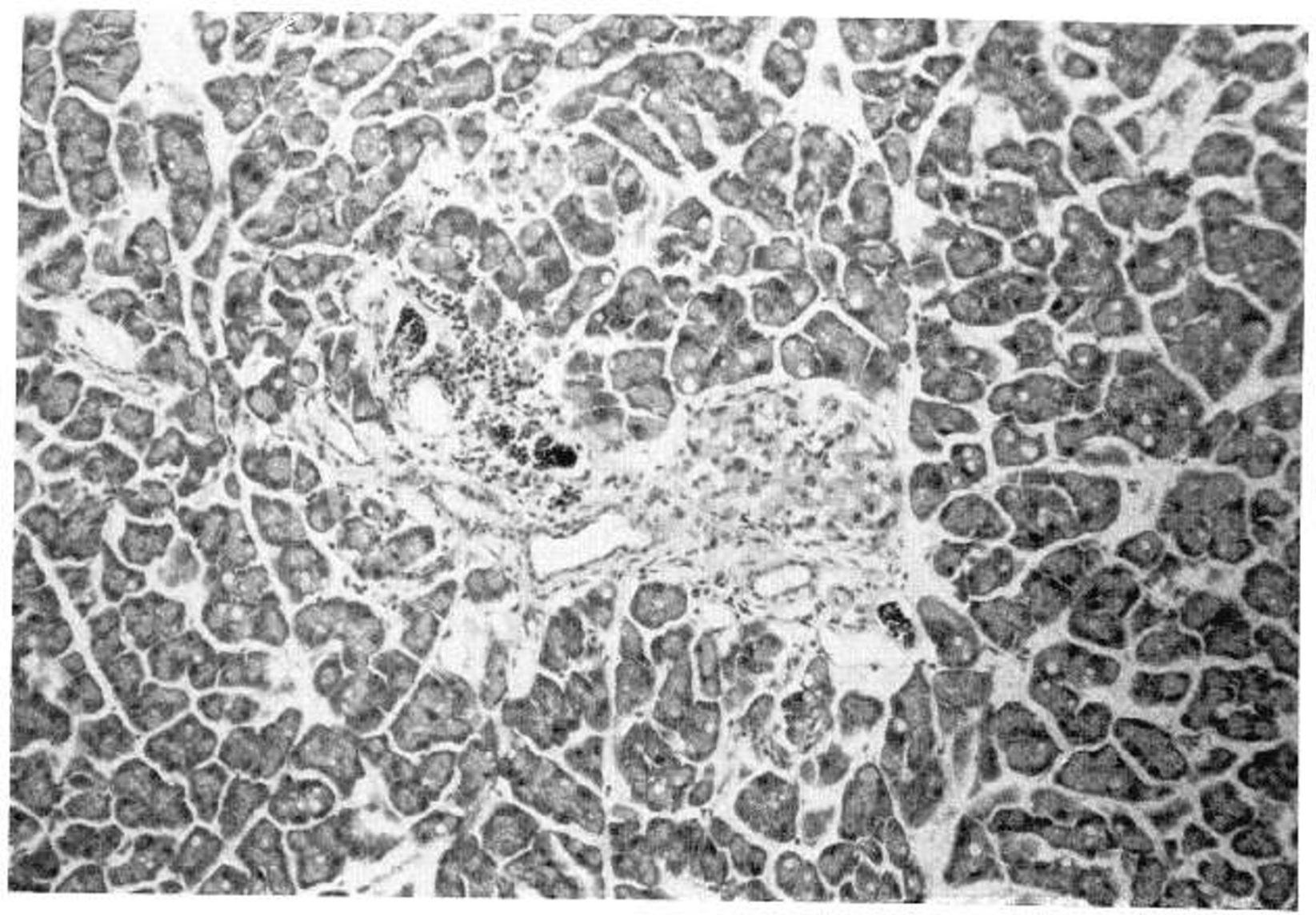

Fig. 4. Illustration of insulitis in the pancreas from a mouse that received streptozotocin alone in Experiment I. The pancreas was obtained on $d$ 60. There were still mild infiltration of mononuclear cells still visible in one of the islets while the infiltration was starting in the other.

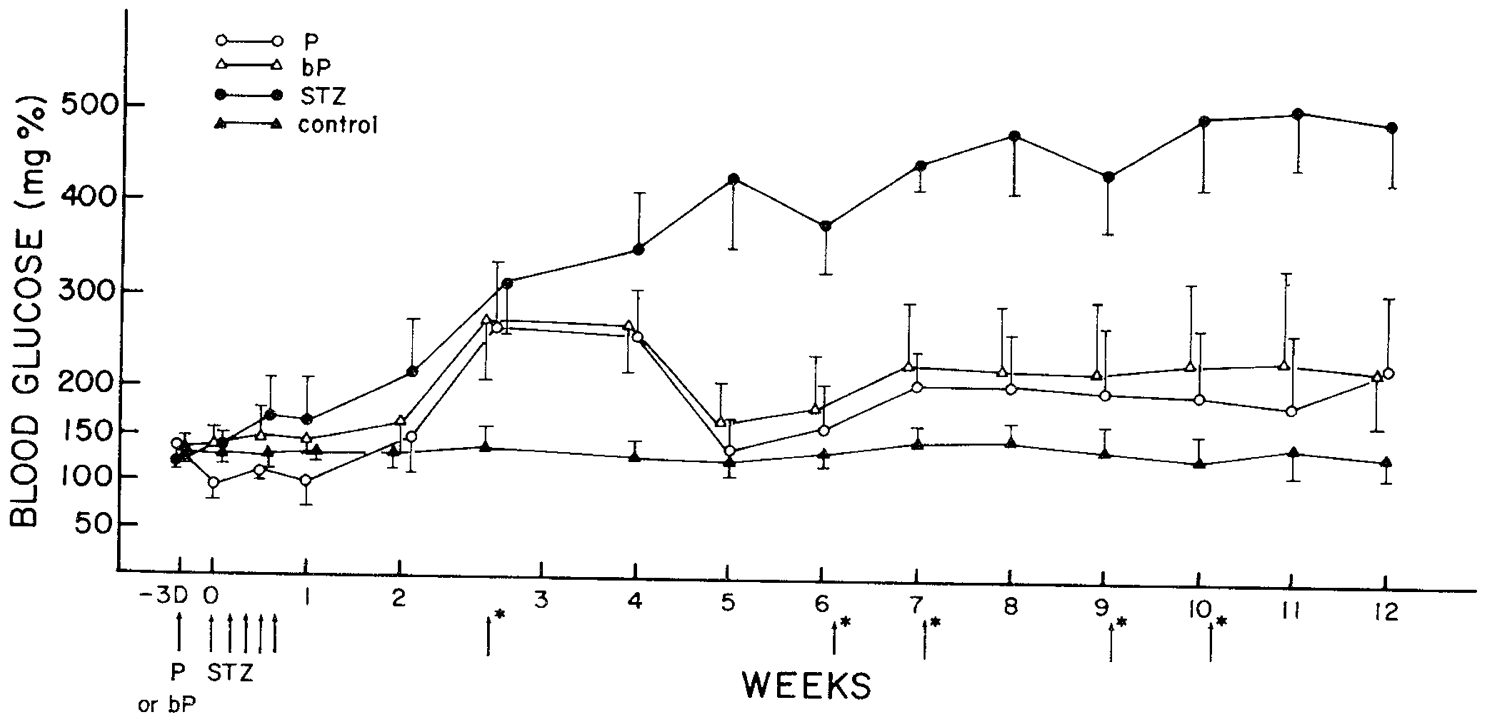

Fig. 5. The sequential changes of blood glucose levels in four groups of mice in Experiment II ( $n=10$ each. except for the control group which had six micc). In one group $(\mathrm{O}-\mathrm{O})$ pertussis vaccine (PV) was given $3 \mathrm{~d}$ before streptozotocin (STZ) injection at a dose of $0.25 \mathrm{ml}$ containing 1.2 $\times 10^{10}$ organisms. Another group $(\triangle-\triangle)$ received the same dose of boiled PV (bPV) $3 \mathrm{~d}$ before the STZ injection. The third group ( me control group $(\mathbf{\Delta}-\mathbf{\Delta})$ only received $0.25 \mathrm{ml}$ of $0.01 \%$ merthiolate solution. * sign indicates the time of injection of the booster of PV $(\mathrm{O}-\mathrm{O})$ or boiled PV $(\triangle-\triangle)$ in cach group. The iertical bars indicate I SD from the mean values. $P$ or bPV indicates initial injection of PV or bPV (see "Materials and Methods" for details).

each time). A hypoglycemic effect of PV was still noticeable: however. single injection of either PV or bPV failed to protect effectively the mice from developing hyperglvcemia in each group (the difference between them was not statistically significant. $P>0.15$ ), although they had significantly lower glucose levels at the end of the experiment as compared with mice either treated with STZ only or control group $(P<0.05$ in either case) Repeated booster injections did, however, reverse hyperglycemia in four of eight mice in PV group or in two of eight mice which received $\mathrm{bPV}$. The result of the number of booster injections required and the number of mice which returned to normoglycemia was listed in Table 2. It appeared that PV was relatively 
Table 2. Effect of booster injections on the return of normoglecemia in diabetic mice*

No. of booster injections

\begin{tabular}{lccccccc} 
Vaccine & $\mathrm{n}$ & $0 \dagger$ & 1 & 2 & 3 & 4 & 5 \\
\hline PV & 10 & 2 & $2 \ddagger(8)$ & $1 \uparrow(6)$ & $1 \ddagger(5)$ & $0(4)$ & $0(4)$ \\
Boiled PV & 10 & 2 & $0 \neq(8)$ & $1 \ddagger(7)$ & $1+(6)$ & $0(6)$ & $0(6)$
\end{tabular}

* Each mouse received five successive. multiple injections of steptozotocin (STZ) initially ( $40 \mathrm{mg} / \mathrm{kg}$ body wt). One dose of either pertussis vaccine (PV) or boiled pertussis vaccine (bPV) was given before STZ injection. Normoglycemia was defined as blood glucose level before 200 mgs.

+ Two mice in each group of PV or bPV never developed hyperglycemia (blood glucose above $200 \mathrm{mg} \%$ in two successive measurements).

F Indicates the number of diabetic mice which returned to normoglycemia. () indicates the total number of diabetic mice which received the booster injection.

effective when it was given at the early stage (between 2-6 wk after the onset) of hyperglycemia whereas bPV was only effective at the mid-stage (between 6-9 wk after the onset) of hyperglycemia. After 8 wk of continued hyperglycemia, neither PV nor bPV would be effective to reverse hyperglycemia (Fig. 5).

\section{DISCUSSION}

Katada and Ui (10) first reported that prior immunization with Bordelella pertussis vaccine reversed hyperglycemic state of diabetic mice injected with STZ. Toyota et al. (25) subsequently observed the reversal of hyperglycemia even in spontaneously occurring diabetic rats after they were immunized with a byproduct of Bordetella pertussis recovered from culture fluid. We recently reported that immunization of $C D-1$ young mice with a dose of PV $3 \mathrm{~d}$ before STZ injection completely protected them from developing diabetes induced by a single injection of $60 \mathrm{mg} /$ $\mathrm{kg} \mathrm{STZ} \mathrm{(9).} \mathrm{The} \mathrm{full} \mathrm{protective} \mathrm{effect} \mathrm{was} \mathrm{evidenced} \mathrm{by} \mathrm{the}$ persistence of normoglycemia, normal results of glucose tolerance tests, normal plasma insulin values, and the lack of appearance of nucleic acid antibodies in the mice immunized with PV (9). Furthermore, there was absence of insulitis in those vaccinated animals as compared with control mice in which inflammation of pancreatic islets were frequently observed $(8,9)$. The inflammation in the islets is thought to be the primary cause of the permanent damage to $\beta$-cells and is an important pathogenetic mechanism leading to the development of IDD.

Our study in Experiment I indicated the anti-diabetogenic effect of PV against STZ was quite extensive. If the vaccine was given from $-10 \mathrm{~d}$ to $+4 \mathrm{~d}$ relative to the day of $\mathrm{STZ}$ injection. the outcome of the protective effect appeared to be identical. If the PV was given $30 \mathrm{~d}$ after STZ which usually would be sufficient to induce hyperglycemia in mice. two-thirds of mice would still revert to normoglycemia after booster injections. As judged from the plasma insulin values and the histologic findings. it is conceivable that in this model using a single STZ injection. the progression of $\beta$-cell damage in islets occurs more slowly than the multiple injection model so that interventions can be more effective in the former. Usually, the onset of hyperglycemia in this model occurs in $2 \mathrm{wk}(13,14.22)$ whereas the former model takes $4-6$ wk after STZ injection $(8,16)$. In the multiple dose model employed in Experiment II, the protection against the development of hyperglycemia was less complete. After numerous booster injections. the outcome was somewhat improved but was significantly less cffective as compared with the results in Experiment 1 . This suggests that even the simple exposure of the animal to toxin such as STZ was considered subdiabetogenic. a repeated or successive exposure would greatly shorten the latency of the development of IDD. This would significantly reduce the optimal time required to practically halt the development of IDD.
The exact mechanism of the protective effect of PV against STZ remains speculative. At least two important biologic components (Pertussigen and endotoxin) contained in cell membrane of Bordetella pertussis may be linked to anti-diabetogenic effect. Pertussigen consists of biologic properties of LPF. HSF, and IAP (20). Although LPF is known to redistribute circulating lymphocytes and thus modifies lymphocyte activity $(1,7)$. IAP would act on $\beta$-cells in islets to enhance its insulin release (26). We confirmed the action of IAP in both Experiment I and II as we noticed the temporary development of hypoglycemia in immunized mice (Fig. 1 and 5). Currently it is believed that the mechanism of the action of IAP on $\beta$-cells in islets appears to be related to its enhancement of adrenergic beta-receptor-mediated process. It seems reasonable, therefore, to speculate that the chain of events timely occurs in $\beta$-cells after the stimulation of IAP effectively reverses or prevents the damage incurred by STZ. This would explain the fact that the immunization with whole vaccine immediately before the exposure of cell toxin such as STZ may be more effective as illustrated in Table 2.

By incubating the whole cell $\mathrm{PV}$ at $80^{\circ} \mathrm{C}$ for $30 \mathrm{~min}$, we were able to distinguish between the effect of the pertussigen and the effect of endotoxin of Bordetella pertussis. The pertussigen is known to be heat labile, therefore, the remaining effect after the treatment only reflects the biologic effect of endotoxin which is heat stable. This was observed by the lack of visible hypoglycemia in mice immediately after the injection of bPV in contrast to the blood glucose change in mice receiving PV (Fig. 5): however, the protective effect of endotoxin was still noticeable as the booster was repeated. As shown in the Table 2. the effect of endotoxin on hyperglycemia was not as prompt as that of pertussigen. This endotoxin of $B$. pertussis is known to possess all the usual biologic components of enterobacterial endotoxins (2) and may act as an immunoregulator by altering the immune response in the host (5). There is also new evidence that suggests phagocyte impotence may be caused by an invasive bacterial adenyl cyclase of $B$. pertussis (4). This may further ameliorate the inflammatory process in the islets by reducing the biochemic outburst of the inflammatory cells, such as macrophages.

The results of the study on the prevention of experimental ( 11 . 15) or human diabetes $(3,6,12,21,23)$, such as ours and others offer an opportunity to re-assess the current management of diabetes in man. Insulin and other supportive care have undoubtedly decreased the mortality caused by IDD as a result of acute ketoacidosis in new patients: however, the prevention of morbidity and mortality resulting from various complications of diabetes occurring in later years has not been satisfactory. This grows out of the fact that the pathogenesis of IDD in man is complex and poorly understood. In some patients there are indications for early intervention to halt the disease process and this early intervention is probably more justified in patients whose early disease process are accompanied with immunologic injury to $\beta$ cells. There are already reports of attempts to halt the disease by employing various immunosuppressants in new patients (3.6. 12. 21, 23). The results of those studies were still too early to assess but more efforts are likely to be attempted as long as the incidence of IDD in man remains unchanged. Future studies focused on the prevention of diabetes should consider: l) developing meaningful parameters to accurately predict the stage of the disease, thus allowing us to determine optimal time for intervention, and 2) evaluating the efficacy of using biologic products such as those produced by $B$. pertussis which is not only an effective immunosuppressant but it also carries other biologic effect which tend to preserve functioning $\beta$-cells.

\section{REFERE.VCES A.VD NOTES}

1. Andersen V Hert, I B. Nicolaisen. E. M.. and Christeson. P. E.: Lymphocytosis promoting factor for B. pertussis: a mitogen for human T-lymphocytes. In: C. R. Manclark and J. C. Hill: Publ. No. (NIH). 79-1830, p. 156 (NIH. Bethesda, Maryland. 1978).

2. Chaby. R.. Ayme. G.. Caroff, M., Donikian, R.. Haeffner-Caraillon, N.. Ledur. 
A.. Moreau, M.. Mynard, M.-C. Roumiantzeff. M.. and Szabo. L.: Structural features and separation of some of the biological activities of the B. pertussis cndotoxin by chemical fractionation. in: C. R. Manclark and J. C. Hill. International Symposium of Pertussis, Publ. No. (NIH) 79-1830, p. 195 (NIH. Bethesda, Maryland. 1978).

3. Cobb, W. E.. Molitch. M., and Reichlin, S.: Levamisole in insulin-dependent diabetes mellitus. N. Engl. J. Med.. 303: 1065 (1980).

4. Confer, D. L. and Eaton, J. W.: Phogocyte importance caused by an invasive bacterial adenyl cyclase. Science. 217: 948 (1982).

5. Dresser, D. W. and Phillips, J. M.: The cellular targets for the action of adjuvants: T-adjuvants and B-adjuvants. Ciba Found. Symp., 18:3 (1973).

6. Elliott. R. B., Crossley. J. R. Berryman, C. C.. and James. A. G.: Partial preservation of pancreatic $\beta$-cell function in children with diabetes. Lancet. 2: 1 (1981).

7. Ho. M-K., Kong, A. S., and Morse, S. I.: The in vitro effect of Bordetella pertussis lymphocytosis-promoting factor on murine lymphocytes. V. Modulation of $\mathrm{T}$-cell proliferation by helper and suppressor lymphocytes. J. Immunol., 24: 36 (1980).

8. Huang. S-W.. and Taylor, G. E.: Immune insulitis and antibodies to nucleic acid induced with streptozotocin in mice. Clin. Exp. Immunol., 43: 425 (1981).

9. Huang. S.-W. and Taylor. G. E.: Pertussis vaccine inhibits immune insulitis induced with streptozotocin. Clin. Exp. Immunol., 48: 375 (1982).

10. Katada, T. and Ui. M.: Spontaneous recovery from streptozotocin induced diabetes in rats pre-treated with pertussis vaccine or hydrocortisone. Diabetologia, 13: 521 (1976).

11. Laupacis, A., Stiller. C. R.. Gardell, C., Keown, P., Dupre, J., and Wallace, A. C.: Cyclosporin prevents diabetes in BB Wistar rats. Lancet. I: 10 (1983).

12. Leslic, R. D. G. and Pyke. D. A.: Immunosuppression of acute insulin dependent diabetes. In: W. J. Irvine: Immunology of Diabetes. p. 345 (Edinburgh: Teviot Scientific Publications, 1980).

13. Like, A. A. and Rossii, A. A.: Streptozotocin-induced pancreatic insulitis: new model of diabetes mellitus. Science. 193:415(1976).

14. Like. A. A.. Appel, M. C.. William. R. M.. and Rossini, A. A.: Streptozotocininduced pancreatic insulitis in mice. Morphologic and physiologic studies. Lab. Invest., 38: 470 (1978).

15. Like, A. A.. Rossini, A. A.. Guberski, D. L., Appel, M. C.. and Williams. R. M.: Spontancous diabetes mellitus: reversal and prevention in the $B B / W$ rat with antiserum to rat lymphocytes. Science, 206:1421 (1979).

16. Maclaren, N. K., Newfeld, M., McLaughlin, J. V., and Taylor, G. E.: Androgen sensitization of streptozotocin-induced diabetes in mice. Diabetes. 29:710 (1980).

17. Mark, V.: An improved glucose-oxidase method for determining blood. CSF and urine glucose levels. Clin. Chem. Acta, 4: 395 (1959).

18. McDowell. E. M. and Trump. B. F.: Histologic fixatives suitable for diagnostic light and electron microscopy. Arch. Pathol. Lab. Med.. 100: 405 (1976).

19. Munoz, J. J. and Bergman. R. K.: Bordetella pertussis-immunological and other biological activities. Immunology Series, Vol. 4, pp. 1-235 (Marce) Dekker, New York. 1977).

20. Munoz, J. J. and Bergman. R. K.: Biological activities of Bordetella pertussis. In: Manclark. C. R. and J. C. Hill. International Symposium of Pertussis, Publ. No. (NIH) 79-1830. p. 143. (NIH, Bethesda. Maryland, 1978).

21. Rand. K. H., Rosenbloom. A. L., Maclaren, N. K.. Silverstein. J. H.. Riley. W. J., Butterworth, B. E., Yoon. J. W., Rubenstein, A. H., and Merigao. T. C.: Human lcukocyte interferon treatment of two children with insulindependent diabetes. Diabetologia. 21:116 (1981)

22. Rossini, A. A., William, R. M., Appel. M. C. and Like, A. A.: Complete protectin from low-dose streptozotocin-induced diabetes in mice. Nature. 276: $182(1978)$.

23. Stiller, C. R., Laupacis, A., Dupre, J., Jenner, M. R., Keown, P. A., Rodger W., and Wolfe. B. M. J.: Cyclosporin for treatment of early type I diabetes: preliminary results. N. Engl. J. Mcd., 308: 1226 (1983).

24. Sumi. T. and Ui, M.: Potentiation of the adrenergic beta-receptor-mediated insulin secretion in pertussis-sensitized rats. Endocrinology, 97: 352 (1975).

25. Toyota, T., Kakizaki. M.. Kimura. K., Yagima, M., Okamoto, T., and Ui. M. Islet cell activating protein (IAP) derived from the culture supernatant fluid of Bordetella pertussis: Effect on spontancous diabetic rats. Diabetologia. 14: $319(1978)$

26. Ui, M.. Katada. T., and Yajima. M.: Islet-activating protein in Bordetella pertussis: Purification and mechanism of action. In: Manclark. C. R. and J. C. Hill: International Symposium of Pertussis, Publ. No. (NIH) 79-1830.p. 166 (NIH. Bethesda. Maryland. 1978)

27. The authors wish to express their thanks to Dr. Raveendran Pottathil for his assistance in the study and to Dr. Tyson Tildon for his review of the manuscript.

28. Requests for reprints should be addressed to: Dr. Shih-Wen Huang. Department of Pediatrics. University of Maryland Hospital, 22 S. Greene Street, Baltimore, Maryland 21201 .

29. Received for publication July 12,1983.

30. Accepted for publication September 27, 1983.

\section{Erratum}

The Publishers regret the misplacement of the important announcement in January issue. The announcement was inadvertently placed on the inside cover instead of page 2 . 